\title{
PEMBERDAYAAN MASYARAKAT DALAM PENGOLAHAN LIMBAH PERTANIAN MENJADI BRIKET, BOKASHI, SILASE, DAN KOMPOS CASCING
}

\author{
Oleh: \\ Noni Himawan, Dedy Hendra Kurniawan, Wahyuni, Alfa Manarul Hidayat, Yulia \\ Supriati, Afifah Fauziyyah, Nurul Islamiah, Widya Istiqomah \\ Universitas Ahmad Dahlan Yogyakarta
}

\section{Ringkasan}

Sampah adalah sesuatu hal yang kebanyakan hanya dibuang tanpa dimanfaatkan kembali. Sampah yang sering kita kenal terbagi menjadi dua, yaitu sampah organik dan sampah anorganik. Sampah organik adalah sampah dedaunan, sisa sayur dan buah-buahan serta limbah peternakan dan pertanian sedangkan sampah anorganik adalah sampah yang terdiri dari plastik, kertas, kaca, dan lain sebagainya. Pengelolaan sampah yang kurang optimal akan membawa dampak negatif. Padahal sampah dapat bermanfaat jika diolah dengan baik. Salah satunya adalah sampah dari limbah pertanian atau peternakan yang dapat diolah menjadi briket, bokashi, silase, dan kompos cacing. Pemanfaatan sampah organik ini dilaksanakan dalam KKN PPM UAD yang dilaksanakan di Dusun Kemirisewu, Desa Sidorejo, Godean, Sleman, Daerah Istimewa Yogyakarta.

Kata Kunci: Sampah Organik, Briket, Bokashi, Silase, Kompos Cacing

\begin{abstract}
Trash is something most of which is just thrown away without being reused. Trash that we often know is divided into two, namely organic waste and inorganic waste. Organic waste is leaf waste, vegetable and fruits waste and farm and agricultural waste while inorganic waste is waste consisting of plastic, paper, glass, and so forth. Less than optimal waste management will have a negative impact. Though garbage can be useful if processed properly. One of them is waste from agricultural waste or farm that can be processed into briquettes, bokashi, silage, and worm compost. Utilization of organic waste is carried out in KKN PPM UAD conducted in Hamlet Kemirisewu, Sidorejo Village, Godean, Sleman, Daerah Istimewa Yogyakarta.
\end{abstract}

Keywords: Organic Waste, Briquettes, Bokashi, Silage, Worm Compost

\section{A. PENDAHULUAN}

Sampah merupakan material sisa yang sudah tidak dipakai, tidak disenangi atau sesuatu yang harus dibuang, yang umumnya berasal dari kegiatan yang dilakukan oleh manusia tetapi bukan kegiatan biologis. Menurut Kamus Besar Bahasa Indonesia, sampah didefinisikan sebagai barang atau benda yang dibuang karena tidak terpakai lagi. Dalam UU No. 18 Tahun 2008 tentang Pengelolaan Sampah, sampah adalah sisa kegiatan seharihari manusia dan/atau proses alam yang berbentuk padat.

Menurut Gelbert dkk, sumber-sumber sampah adalah sebagai berikut:

1. Sampah permukiman, yaitu sampah rumah tangga berupa sisa pengolahan makanan, perlengkapan rumah tangga bekas, kertas, kardus, gelas, kain, sampah kebun/ halaman, dan lain-lain.

2. Sampah pertanian dan perkebunan, sampah kegiatan pertanian tergolong bahan organik, seperti jerami dan sejenisnya. Sebagian besar sampah yang dihasilkan selama musim panen dibakar atau dimanfaatkan untuk pupuk. Untuk sampah bahan 
kimia seperti pestisida dan pupuk buatan perlu perlakuan khusus agar tidak mencemari lingkungan. Sampah pertanian lainnya adalah lembaran plastik penutup tempat tumbuh-tumbuhan yang berfungsi untuk mengurangi penguapan dan penghambat pertumbuhan gulma, namun plastik ini bisa di daur ulang.

3. Sampah dari sisa bangunan dan konstruksi gedung. Sampah yang berasal dari kegiatan pembangunan dan pemugaran gedung ini bisa berupa bahan organik maupun anorganik. Sampah organik, misalnya: kayu, bambu, triplek. Sampah anorganik, misalnya: semen, pasir, spesi, batu bata, ubin, besi dan baja, kaca dan kaleng.

4. Sampah dari perdagangan dan perkantoran. Sampah yang berasal dari daerah perdagangan seperti: toko, pasar tradisional, warung, pasar swalayan ini terdiri dari kardus, pembungkus, kertas, dan bahan organik termasuk sampah makanan dan restoran. Sampah yang berasal dari lembaga pendidikan, kantor pemerintah dan swasta biasanya terdiri dari kertas, alat tulis-menulis (bolpoint, pensil, spidol dan lain-lain), toner foto copy, pita printer, kotak printer, baterai, bahan kimia dari laboratorium, pita mesin ketik, klise film, komputer rusak, dan lain-lain. Baterai bekas dan limbah bahan kimia haurs dikumpulkan secara terpisah dan harus memperoleh perlakuan khusus karena berbahaya dan beracun.

5. Sampah industri, yaitiu sampah yang berasal dari seluruh rangkaian proses produksi berupa bahan-bahan kimia serpihan atau potongan.

Berdasarkan bahan asalnya sampah dibagi menjadi dua jenis yaitu sampah organik dan anorganik.11 Sampah organik adalah sampah yang dapat diuraikan secara alami, seperti sampah yang berasal dari dedaunan, sisa sayur dan buah-buahan serta limbah peternakan dan pertanian. Sedangkan sampah anorganik adalah sampah yang tidak dapat diuraikan secara alami, seperti sampah yang berasal dari plastik, kertas, kaca, dan lain sebagainya. Sampah organik maupun anorganik selama ini dirasakan dalam pengelolaannya masih kurang maksimal. Banyak sampah yang hanya dibiarkan dan ditumpuk tanpa ada tindakan lebih lanjut. Sampah yang menumpuk tanpa ditindak lanjuti hanya akan membawa dampak negatif bagi masyarakat. Dampak negatif tersebut diantaranya adalah terjadinya pencemaran lingkungan dan juga dapat menyebabkan bencana alam karena pengelolaan sampah yang tidak baik.

Keadaan di atas akan sangat berbahaya sekali jika sampah tidak dikelola dengan baik. Sampah bagi masyarakat hanya merupakan sesuatu yang tidak bermanfaat dan tidak dapat dimanfaatkan yang cenderung hanya dibuang begitu saj tanpa peduli kemanfaatannya. Padahal, sampah-sampah tersebut dapat digunakan untuk hal-hal yang memberikan manfaat dalam kehidupan sehari-hari. Misalnya sampah organik seperti dedaunan yang dapat digunakan sebagai pupuk kompos, sisa-sisa makanan untuk pelet ternak, dan lain sebagainya. Hal ini akan sangat berguna bagi masyarakat dan juga mengurangi dampak buruk dari penumpukan sampah.

Sekarang ini, banyak alternatif pengolahan sampah, khususnya sampah organik. Diantaranya adalah briket, bokashi, silase, dan kompos cacing. Briket adalah pemanfaatan daun-daun kering, ranting kayu maupun tempurung kelapa untuk diolah menjadi salah satu alternatif pengganti bahan bakar. Bokashi adalah sama seperti pupuk kompos biasa namun 
dalam pembuatannya difermentasi dengan menggunakan EM4. Sehingga, bokashi dapat dihasilkan dengan waktu yang lebih cepat dibandingkan pupuk kompos biasa. Bokashi dapat diolah dari limbah pertanian dan peternakan. Silase adalah pakan ternak dari hijauhijauan yang difermentasi. Silase dapat menjadi salah satu solusi untuk pakan ternak ketika terjadi musim kemarau dimana tidak ada rumput segar untuk pakan ternak. Kompos cacing adalah pupuk dari kotoran cacing. Pupuk kotoran cacing mempunyai nilai unsur hara yang lebih tinggi dibandingkan dengan pupuk kompos biasa.

Alternatif pengolahan sampah tersebut dapat menjadi salah satu solusi untuk mengatasi menumpuknya sampah organik yang dibiarkan tanpa pengolahan lebih lanjut. Hal inilah yang akan kami berdayakan di dusun Kemirisewu, Sidorejo, Godean, Yogyakarta. Untuk memanfaatkan limbah pertanian menjadi briket, bokashi, silase, dan kompos cacing.

\section{B. METODE PENGABDIAN}

Metode pengabdian yang digunakan yaitu:

1. Metode Ceramah

Metode ceramah digunakan untuk menyampaikan teori dasar yang harus dipahami oleh masyarakat sebelum melakukan praktik. Metode ini juga dilengkapi dengan pembagian leaflet yang berisi alat, bahan, dan cara kerja dari briket, bokashi, silase, dan kompos cacing. Leaflet ini diberikan untuk menambah pemahaman masyarakat terhadap materi yang disampaikan.

2. Praktik

Metode praktik ini, masyarakat akan melihat secara langsung dan ikut serta untuk membuatan briket, bokashi, silase, dan kompos cacing dari awal sampai jadi produk yang siap digunakan dan dikemas. Dengan metode ini, diharapkan masyarakat dapat mempraktikan dengan mandiri.

\section{PEMBAHASAN}

Pengabdian masyarakat KKN PPM Universitas Ahmad Dahlan ini dilaksanakan di dusun Kemirisewu, desa Sidorejo, Godean, Sleman, Daerah Istimewa Yogyakarta. KKN PPM dilaksanakan selama 35 hari di dusun tersebut dengan sasaran kegiatan adalah kelompok tani dan ibu-ibu PKK. Kelompok tani dan ibu-ibu PKK yang diundang dalam pelatihan berjumlah masing-masing 30 orang yang terdiri dari RT 01 sampai RT 06 dengan masing-masing RT 5 orang. Jadwal pelatihan ibu-ibu PKK dan kelompok tani dibuat di waktu yang berbeda yaitu ibu-ibu PKK pada siang hari dan kelompok tani pada malam hari. Jumlah pertemuan untuk pelatihan ibu-ibu PKK dan kelompok tani masing-masing adalah 15 kali pertemuan. Pelatihan ini dilaksanakan di masjid Al-Muttaqin di dusun Kemirisewu.

Tema yang diangkat dalam pengabdian masyarakat ini adalah pengolahan dan pemanfaatan limbah pertanian. Limbah pertanian yang melipah di dusun kemirisewu sebagain besar hanya menjadi pakan ternak bagi yang memiliki ternak dan yang tidak memiliki ternak lantas hanya dibiarkan mengering begitu saja. Hal inilah yang menjadi titik perhatian dari KKN PPM ini. Dengan limbah pertanian yang melimpah, dapat diolah 
menjadi sesuatu hal yang bermanfaat bagi warga dusun Kemirisewu. Diantaranya dapat diolah menjadi briket bioarang, bokashi, silase, dan kompos cacing. Briket bioarang adalah salah satu alternatif pengganti minyak tanah yang dapat digunakan sebagai bahan bakar untuk rumah tangga. Briket ini mudah dibuat dan mudah digunakan sebagai bahan bakar. Bahan-bahan untuk membuat briket adalah menggunakan sampah organik yaitu, dedaunan kering, ranting kayu dan tempurung kelapa serta menggunakan kanji dan air untuk membuat lem kanji. Briket dibuat dengan cara membakar sampah organik menjadi arang kemudian ditumbuk halus dan diayak untuk menghasilkan bubuk arang yang halus. Setelah itu, bubuk arang yang halus dicampur dengan lem kanji sampai membentuk massa yang dapat dicetak. Selanjutnya proses pencetakan briket, dapat menggunakan alat cetak atau pipa yang sudah tidak tepakai. Setelah dicetak maka dikeringkan sampai kering dan briket siap digunakan.

Produk kedua yang dibuat adalah bokashi. Bokashi merupakan pupuk kompos yang dibuat secara fermentasi dengan menggunkan EM4. Hasil yang diperoleh dari bokashi ini adalah bokashi padat dan bokashi cair. Karena dalam sekali pembuatan menghasilkan bokashi padat dan cair. Bokashi padat dapat menggunakan kotoran sapi, sisa-sisa sayuran atau rumput gajah yang disimpan di dalam karung. Bokashi cair dapat menggunakan air bilasan beras, terasi, EM4, dan tetes tebu. Cara pembuatannya adalah bokashi cair dimasukkan ke dalam tong dan kemudian dimasukkan karung bokashi padat ke dalam tong tersebut. Selanjutnya didiamkan selama 7-10 hari untuk fermentasi. Setelah 7-10 hari bokashi cair dapat langsung digunakan tetapi bokashi padat dikeringkan terlebih dahulu sebelum digunakan. Bokashi padat dan cair dapat menjadi alternatif pemanfaatan limbah pertanian dan peternakan dan juga pembuatannya lebih cepat dibanding pupuk kompos biasa yang relatif lebih lama karena bokashi ini menggunakan EM4 untuk fermentasinya.

Produk ketiga adalah silase. Silase merupakan pakan ternak yang difermentasi untuk mempertahankan nilai gizi yang ada pada hijau-hijauan yang digunakan. Silase merupakan salah satu alternatif pakan ternak yang dapat digunakan ketika terjadi musim keramau dan juga untuk memanfaatkan hijau-hijauan yang banyak di dusun kemirisewu. Sehingga dapat digunakan untuk pakan ternak daripada dibiarkan tanpa ada pengolahan yang tepat. Bahan-bahan untuk membuat silase adalah hijau-hijauan seperti rumput gajah atau jerami, dedak halus, dan molasse atau tetes tebu. Semua bahan tersebut dicampur dan dimasukkan ke dalam tong atau silo untuk menyimpan silase selama masa fermentasi. Masa fermentasi silase yaitu selama 3 minggu dan masa penyimpanan silase yaitu selama 6 bulan.

Produk keempat yang dibuat adalah kompos cacing. Kompos cacing merupakan salah satu alternatif pupuk kompos selain menggunakan pupuk kompos biasa. Kompos cacing mengandung unsur hara yang tinggi. Kompos cacing dihasilkan dari kotoran cacing yang dibubidayakan. Untuk mendapatkan kompos cacing harus membudidayakan cacing terlebih dahulu dengan menggunankan media ternak cacing. Pembuatan media cacing adalah menggunakan kotoran ternak, tanah, dan grajen. Media cacing dapat dijadikan kompos cacing setelah pemanenan cacing dan telur-telur cacing pada media cacing dapat diternak kembali di media cacing sedangkan cacing yang dipanen dapat langsung dijual atau dibuat obat. Makanan ternak cacing adalah sayuran-sayuran sisa. Kompos cacing bukan hanya sebagai alternatif pupuk tetapi juga memanfaatkan sisa-sisa sayuran yang terbuang percuma dapat menjadi bermanfaat yaitu sebagai makanan cacing. Pemeliharaan 
ternak cacing juga harus diperhatikan keadaan media ternak cacingnya. Media ternak cacing harus dipelihara kelembapan nya. Media tidak boleh kering maupun basah tetapi hanya lembab saja.

Keempat produk yang diolah dan diberikan pelatihannya ke warga kemirisewu dengan metode ceramah dan praktik. Metode ceramah digunakan untuk menjelaskan materi kepada warga kemirisewu untuk dapat memahami materi yang disampaikan. Dan juga metode praktik, supaya warga dapat mempraktekkan secara langsung terhadap apa yang dijelaskan selama penyampaian materi. Warga terlihat antusias terhadap pelatihan ini karena terdapat beberapa pertanyaan dari warga yang hadir selama penyampaian materi maupun praktek.

Selama pelatihan kondisinya berjalan dengan lancar dan baik. Tetapi ada beberapa kendala yang dihadapi selama pelatihan yaitu:

1. Kurangnya fasilitas pendukung untuk presentasi saat pelatihan seperti LCD proyektor.

2. Kesulitan untuk menyesuaikam waktu dengan warga kemirisewu untuk mengadakan pelatihan. Karena kesibukan warga yang berbeda-beda, yang harus disesuaikan agar dapat berlangsungnya pelatihan

Kendala-kendala di atas tidak terlalu mengganggu jalannya pelatihan yang diadakan. Pelatihan masih dapat berjalan lancar dan sesuai dengan yang diharapkan.

Harapan terhadap pelatihan ini adalah dapat memberikan ilmu yang bermanfaat, dapat dipraktikkan dan dimanfaatkan untuk kehidupan sehari-hari, serta dapat dijadikan sebagai peluang usaha yang bernilai ekonomis bagi warga dusun Kemirisewu

\section{KESIMPULAN}

Berdasarkan hasil pelatihan ini dapat disimpulkan bahwa pelatihan yang diberikan dapat dipahami dan diterapkan oleh warga dusun Kemirisewu.

Saran

Berdasarkan hasil pelatihan, terdapat beberapa saran, diantaranya:

1. Melakukan uji kualitas terhadap bokashi padat dan bokashi cair yang dihasilkan

2. Melakukan uji kualitas terhadap silase yang dihasilkan

3. Melakukan penyuluhan tentang pengemasan produk supaya dapat bernilai ekonomis

\section{DAFTAR PUSTAKA}

Cecep Dani Sucipto, Teknologi Pengolahan Daur Ulang Sampah, (Jakarta: Goysen Publishing, 2009), hlm. 2-3.

Fadhilah, Arief., Sugianto, Heri., Hadi, Kuncoro., dkk, 2011, Kajian Pengelolaan Sampah Kampus, MODUL Vol. 11 No. 2 Agustus 2011

M. Gelbert, dkk., Konsep Pendidikan Lingkungan Hidup dan "Wall Chart”. Buku Panduan Pendidikan Lingkungan Hidup, (Malang: PPPGT/VEDC, 1996). 
